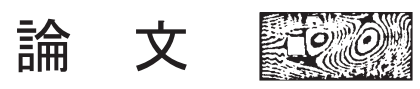

\title{
通気工法を用いた外壁システムの風荷重評価に関する研究 \\ Evaluation of Wind Loads on Ventilated Exterior Wall Systems
}

渡部 慶* 1

Kei WATANABE
植松 康*2

Yasushi UEMATSU

\section{SUMMARY}

Ventilated exterior wall systems are commonly used for low-rise buildings, such as residential houses. Because the net wind force on the external wall is the difference between external pressure and ventilation layer pressure, the load may be reduced due to the effect of pressure equalization. On the other hand, the ventilation layer pressure acts on the internal walls such as drywalls, which is not considered in the conventional wind-resistant design of walls. The present paper discusses this subject based on a wind tunnel experiment of the external pressures as well as on a numerical simulation of the vent-layer pressure. Based on both of the experimental and analytical results, wind force on each member is evaluated and a design guide is proposed for the ventilated exterior wall systems.

key words: Wall, Ventilation layer, Internal pressure, Wind force, Numerical simulation

1.はじめに

本研究では，低層住宅の外壁として広く普及している 通気工法を利用した外壁を対象とし, 適切な風荷重評価 方法について検討する。図 1 に通気工法による外壁の例 を示すが，本論文では外壁を構成するサイディングと胴 縁に加えて内装材までを含めた壁全体を「外壁システム」 と定義し, 外壁システムにおける風荷重を評価する方法 を提案する。サイディングの裏に設けられた通気層内の
圧力 (以下,「層内圧」と呼ぶ) は外圧分布や隙間の状況に 伴って変化する。隙間等により層内圧が外圧に近づくよ うに変化することをここでは「等圧効果」と呼ぶが，サ イディングに作用する風力は外圧と層内圧の差であるか ら，等圧効果によって荷重が低減されることが期待され る。一方で, 層内圧と室内圧の差で与えられる風力が内 装材に作用するが，その荷重の検討は通常行われない。 住宅等に多用される石膏ボードなどの内装材には，ほと

\footnotetext{
* 1 国土交通省関東地方整備局 (当時 東北大学大学院生) Kanto Regional Development Bureau

* 2 東北大学大学院工学研究科都市 - 建築学専攻 教授

Professor, Department of Architecture and Building Science, Graduate School of Engineering, Tohoku University (原稿受理年月日：2018 年 2 月 7 日，採用決定年月日：2019年 1 月 27 日)
} 
んど耐力が見込めず，大きな荷重が作用すると破損の恐 れがある。

一般に，外壁の設計ではサイディングが外圧を全て負 担すると仮定して行われる。しかし，この方法では等圧 効果が考慮されていないため, サイディングの荷重を過 大評価することになる一方で，内装材の荷重が考慮され ておらず，合理的な設計とは言えない。

通気工法は, 壁体内の防湿性向上という環境工学的な 観点から開発され普及したものである。そのため, これ まで通気性状に関する研究は多く為されているが，等圧 効果を考慮した風荷重評価を含め, 外壁システムとして の而風性という観点からの検討は全く為されていない。 そこで, 本研究では外圧だけでなく層内圧の影響も考慮 することで, 内装材も含めた外壁システムの風荷重特性 を把握し, 合理的な風荷重評価方法を検討する。

一般的な通気層の厚さは $20 \mathrm{~mm}$ 程度と狭いため, 縮尺 模型を用いた風洞実験で層内圧を直接測定することはで きない。しかし，隙間や開口の形状と開口流れの性状， 並びに，隙間や開口位置に作用する外圧の時刻歴が分か れば，通気層内の流れや層内圧をシミュレーションによ って把握することは可能である。本研究では, 非定常べ ルヌーイ方程式を用いたシミュレーション手法を通気層 内の流れに適用し, 風洞実験で得られた壁面外圧の時刻 歴データから層内圧をシミュレートする。通気層のモデ ル化に当たっては, 実物大の通気層の一部を模した試験 体に変動外圧を作用させて層内圧を測定する実験(以下， 実物大動風圧載荷実験)を行う。これにより外壁の構成部 材と壁面に作用する荷重を実状況に近い形で再現し，隙 間・開口の流体力学的特性を求めることができる。そし て, 風洞実験による多点外圧データとシミュレーション による層内圧データを組み合わせて風力を計算し，その 特性を把握することで, 外壁システムの風荷重評価方法 について検討寸る。なお, 本研究の検討対象は国内で広 く普及が進んでいる金属サイディングとするが，致業系 などの他素材のサイディングでも同様の施工方法であれ ば本研究の結果を適用することは可能である。

\section{2. 壁面外压測定実験}

本論文では，低層住宅を模した模型を用いて風洞実験 を行い，壁面に作用する外圧を測定する。この外圧時刻 歴を, 実変動風圧載荷実験の入力荷重の作成に用いると ともに，壁面全体の層内圧をシミュレーションする際の 入力值とする。対象とする建物は図 2 および図 3 に示す 切妻型軒付き低層建物である。低層住宅を想定して軒付

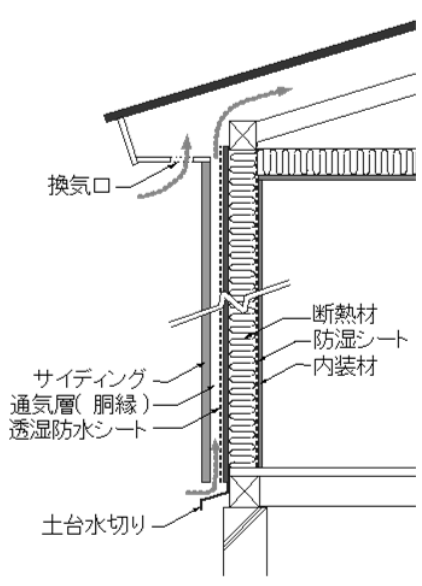

図 1 通気工法外壁の例

Fig. 1 An example of ventilated exterior wall system

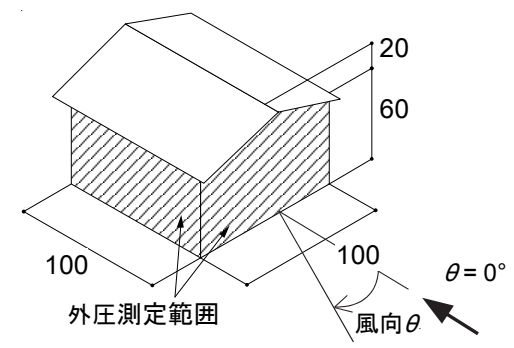

図 2 実験模型と風向の定義（unit: $\mathrm{mm}$ )

Fig. 2 Experimental model for pressure measurements and definition of wind direction in the wind-tunnel experiment

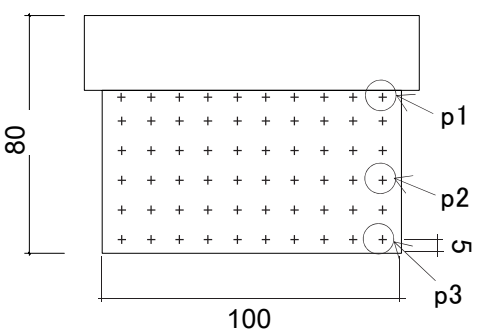

(a) 析行面

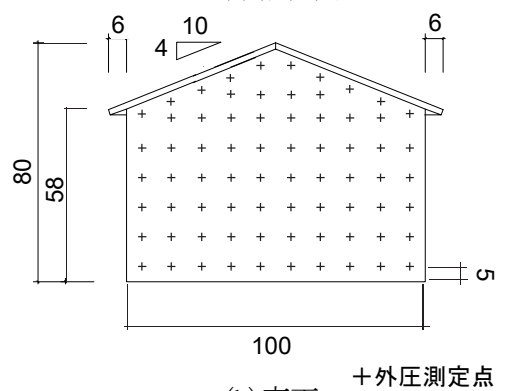

(b) 妻面

図 3 圧力測定孔配置 (単位 $\mathrm{mm}$ )

Fig.3 Layout of pressure taps on the model 
きのモデルとし，軒高は $6 \mathrm{~m}$, 平面辺長比は 1 とする。 屋根勾配は一般的な住宅の屋根勾配である 4 寸勾配(約 $22^{\circ}$ ), 軒の出は $0.6 \mathrm{~m}$ とする。図 3 に示寸ように桁行壁面 に 60 点, 妻面に 72 点の外圧測定孔が設けられており, 風洞実験では壁面に作用する外圧を全点同時測定する。

実験気流は, 日本建築学会・建築物荷重指針 ${ }^{1)}$ に示さ れる地表面粗度区分亚に概ね相当寸る境界層乱流である。 風向 $\theta$ は, 妻面に正対する風向を $0^{\circ}$ と, 模型の対称性 を考慮して桁行面については- $90^{\circ} \sim 90^{\circ}$, 妻面については

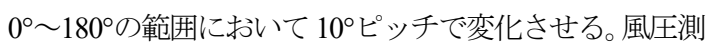
定のサンプリング周波数は $800 \mathrm{~Hz}$ とし, 実時間で 10 分 間相当のデータを各ケース 10 組取得する。なお, チュー ビング補正は，計測システムの周波数応答関数を用いて 周波数領域で行う。

\section{3. 実物大動風圧載荷実験}

3. 1 実験方法の概要

本研究では, 実物大の通気層の一部を模した試験体に 変動外圧を作用させて層内圧を測定する。そして, 本実 験データを用いて 4 章の数值シミュレーションモデルに 与える適切な隙間の特性值を決定する。通気層の詳細図 を図 4 に示寸。通気層内で流れが生じる箇所として, (1) サイディング嵌合部の隙間, (2)胴縁間の開口, (3)上下端 の開口の 3 箇所がある。本実験では, それぞれの流れの 挙動を表すパラメータ值を適切に定めるため, 嵌合部の 隙間流れのみが生じる単室試験体, 嵌合部と通気層の上 下端および同縁間に流れが生じるアセンブリ試験体の 2 種類の試験体を用いる。

また, 本実験で用いる変動外圧は, 風洞実験で負の最 大ピーク風圧が発生した風向 $\theta=0^{\circ}$ において, 正または負 のピーク外厓発生した外圧測定点での風圧の時刻歴を, 設計風速 $15 \mathrm{~m} / \mathrm{s}$, 模型の幾何学的縮尺率 $1 / 100$ を用いて実 スケールに換算したものを用いる。図 5 には, 負のピー

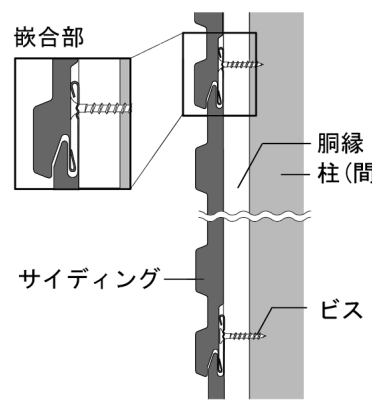

図 4 通気層の詳細図

Fig.4 Details of ventilation layer
ク風圧を含む変動風圧時刻歴の入力荷重を示す。なお, 本実験では載荷する変動外圧と変動内圧の関係を測定す ることを目的とするため, 試験体面積に対する風圧の面 平均操作は行っていない。変動風圧の載荷には Pressure Loading Actuator (PLA) ${ }^{2)}$ を利用した圧力箱方式の動風圧 載荷装置を用いる。試験体を圧力箱に設置し，ホースを 介して圧力箱に接続した PLA によって空気を吸排気す ることで, 圧力を試験体表面に作用させる。この装置で は, 計測された圧力箱内の圧力值が目標とする入力荷重 の圧力值に合うようにフィードバック制御を行い, 吸排 気量を瞬時に変化させることにより，高い追従性をもつ て目標とする変動風圧を再現する。なお, PLA で十分に 再現ができない高周波成分を取り除くため, 入力荷重に はカットオフ周波数 $5.0 \mathrm{~Hz}$ のデジタルローパスフィルタ 一をかけている。また, 層内圧の測定には内径 $6 \mathrm{~mm} の$ ビニルチューブに接続した圧力変換器を用いる。使用し たチュービング系の周波数応答関数は $5.0 \mathrm{~Hz}$ 以下の範囲 ではほとんど出力への影響がないため, チュービング補 正は行っていない。

なお，勘合部の隙間は通気層上下端の開部口に比べて 非常に小さいことから, 本論文では嵌合の隙間形状が変 化することによる影響は無視する。そのため, 本実験の 荷重はサイディングに大きな変形が生じない風圧レベル に設定している。

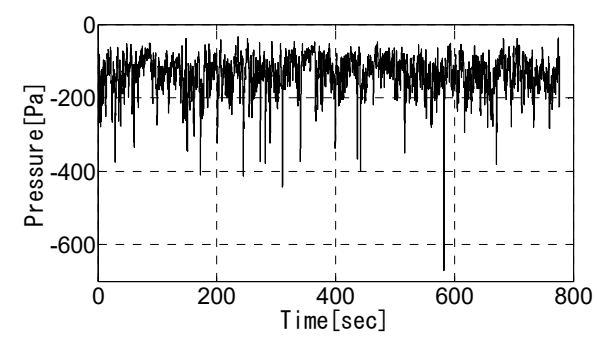

図 5 作成した入力荷重(負圧の場合)

Fig.5 A pressure trace for suction loading

3. 2 単室試験体を用いた実験

まず, 嵌合部の隙間での流れの再現に着目し, サイデ イングの裹に厚さ $18 \mathrm{~mm}$ の裹面空間をもつ単室試験体 (図 6)を用いた実験を行う。試験体のサイディング周囲 のフレームとの隙間は変性シリコーン系コーキング材で シールされており, 嵌合部以外から空気の漏れはない。 実験では, サイディング表面に作用する外圧の変動に伴 って変動する裏面空間の内圧は, 図 6 に示寸圧力測定孔 に導圧チューブと圧力変換器を取り付け, 実験室内の圧 力を基準にしたゲージ圧として測定する。サンプリング 
周波数は $200 \mathrm{~Hz}$ である。また，嵌合部の隙間量が施工に よりばらつく可能性があるため, 2 体の試験体を用いて 実験を行う。

・ビス(表から見える)。ビス(表から見えない)

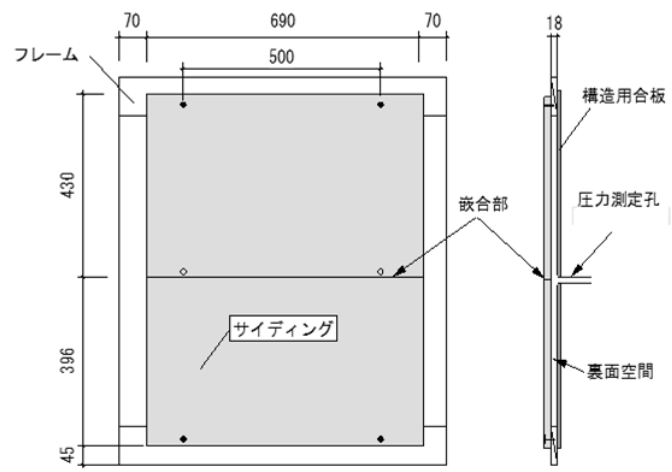

[水平方向断面]

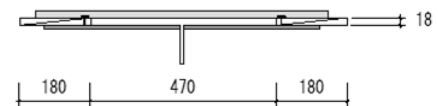

図 6 単室試験体(単位 $\mathrm{mm}$ )

Fig.6 Details of single-room model specimen

\section{3．３アセンブリ試験体を用いた実験}

通気層上下端の開口と胴縁間の開口に生じる流れの再 現に着目し, 実際の施工方法 ${ }^{3)}$ により通気層の一部を再 現したアセンブリ試験体(図 7)を用いた実験を行う。胴 縁は，サイディングメーカーの施工基準 ${ }^{3)}$ の最小の断面 寸法を満たす $18 \mathrm{~mm} \times 45 \mathrm{~mm}$ の断面の木材とする。また, 圧力測定は単室試験体の場合と同様の方法で行い, 図 7 に示す Line1 4 の高さに 2 点ずつ設けた合計 8 点の測定 孔で行う。また, 通気層の下端は圧力箱内に, 上端は圧 力箱外 (実験室内の圧力は基準圧 $0 \mathrm{~Pa}$ とする) に開放する。

本実験では, 通気層内の開口率や開口形状の影響を把 握するため, 表 1 に示すようにパラメータを変化させた 4 種類の試験体を 1 体ずつ用いて実験を行う。図 7 に示 すようにサイディングの張り方は横張りと縦張りの 2 種 類とし，下地である胴縁の向きによって異なる通気層内 の開口形状の影響について検討する。さらに, 縦張りの 場合は, 図 7 (a) に示寸横同縁間の隙間 $C$ を $30 \mathrm{~mm}$ および $60 \mathrm{~mm}$ とした場合と, 図 8 のように断面に切欠き $(9 \mathrm{~mm}$ $\times 50 \mathrm{~mm} @ 150 \mathrm{~mm}$ )を設けた胴縁(以下，切欠き胴縁）を用 いた場合の 3 パターンとする。切欠きの形状等は一般に 流通している胴縁の形状を参考にした。なお，サイディ ングと胴縁との隙間は胴縁間の隙間に対して小さいため 無視し, 通気層内開口面積は胴縁間の隙間面積と等しい ものとする。
切欠き胴縁の場合は $C=0$

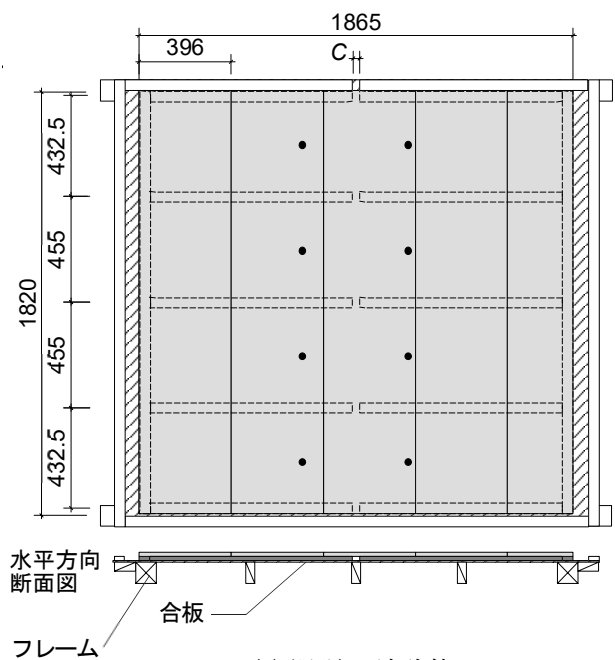

鉛直方向 断面図

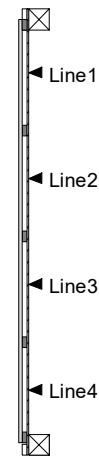

(a) 縦張り試験体

\section{胴縁 [--- 胴縁(表から見えない) ○ 層内圧測定点}
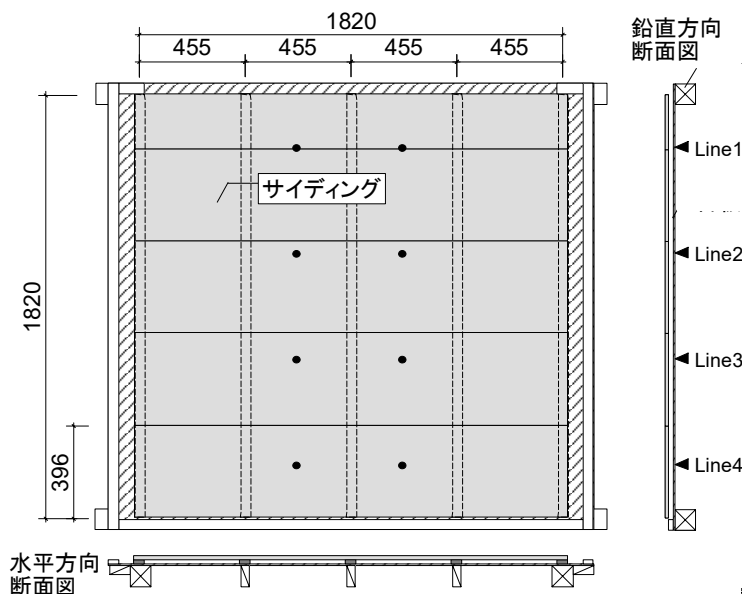

(b) 横張り試験体

図 7 アセンブリ試験体(単位 $\mathrm{mm}$ )

Fig.7 Details of assembled wall specimen

表 1 アセンブリ試験体のパラメータ

Table.1 Parameters of the assembled wall specimens

\begin{tabular}{c|cccc}
\hline & $\begin{array}{c}\text { サイディン } \\
\text { グの試り験体 }\end{array}$ & $\begin{array}{c}\text { 胴縁の } \\
\text { 切欠き }\end{array}$ & $\begin{array}{c}\text { 胴縁間隔 } \\
{[\mathrm{mm}]}\end{array}$ & $\begin{array}{c}\text { 通気層内 } \\
\text { 開口面積 } \\
{\left[\mathrm{mm}^{2}\right]}\end{array}$ \\
\hline V-C30 & & 無し & 30 & 540 \\
V-C60 & 縦張り & 無し & 60 & 1080 \\
V-AH & & 有り & 0 & 5260 \\
H & 横張り & - & 410 & 7380 \\
\hline
\end{tabular}




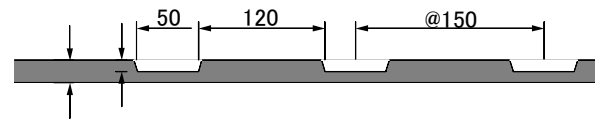

図 8 切欠き胴縁の断面図

Fig.8 Cross section of cut-out furring strip

4. 層内圧シミュレーションモデル

4. 1 シミュレーション手法

層内圧の計算には, 非定常ベルヌーイ方程式に圧力損 失を考慮した Oh et al. ${ }^{4}$ の方法を用いる。まず, 通気層内 をいくつかの仮想室に分割し, 各仮想室の圧力は一様で あると仮定する。いま, 仮想室 $(i, j)$ の内圧を $P_{i, j}$, 外圧ま たは隣接する仮想室の内圧を $P$ とし, 開口部および仮想 室間の流れを層流と仮定すると， $P_{i, j}$ と $P$ の関係は式(1) のように表される。

$$
\begin{aligned}
\rho l \dot{U}= & P_{i, j}-P-\left(\frac{1}{k}\right)^{\frac{1}{n}} \cdot\left(\frac{\rho}{2}\right)^{\frac{1}{2 n}} U|U| \\
& -\frac{64 v}{U d} \cdot \frac{l}{d} \frac{\rho}{2} U|U|
\end{aligned}
$$

ここに, $\rho:$ 空気密度 $\left[\mathrm{kg} / \mathrm{m}^{3}\right], l:$ 隙間の深さ $[\mathrm{m}], U:$ 流速 $[\mathrm{m} / \mathrm{sec}], k$ : 流量係数, $n$ : 流孔指数 $(=0.5 \sim 1.0), d$ : 隙間の代表寸法 $[\mathrm{m}], v$ : 動粘性係数 $\left[\mathrm{m}^{2} / \mathrm{sec}\right]\left(20^{\circ} \mathrm{C}\right.$ 空 気では, $\left.v=1.512 \times 10^{-5}\right)$ である。

また, 質量保存則より, 各仮想室の内圧変化は式(2) のように表される。ここに, $\gamma$ : 比熱比 $(=1.4), A$ : 隙間 の断面積 $\left[\mathrm{m}^{2}\right], \quad N$ : 仮想室数である。

$$
\dot{P}=\frac{\gamma P_{0}}{V_{0}} \sum_{m=1}^{N} k_{m} A_{m} U_{m}
$$

ここで, 通気層内の水平方向, 鉛直方向の流れをそれぞ れ $x, z$ 方向流れ, 嵌合部を通る外部から通気層一の流れ を $y$ 方向流れと定義する。各方向の流れに式(1)を適用し て隙間や開口を通過する流速を 4 次 Runge-Kutta 法およ びEuler 法によって計算する。次に, 式(2)で仮想室への 空気の流出入の釣り合いを考慮することにより，ある時 刻における内圧を求めることができる。さらに，全ての 仮想室の流れにこれらの式を適用し，それらを連立させ て解くことによって風洞実験による各点の外圧データを 入力值として層内圧時刻歴を求める。

4. 2 通気層の流れ性状のモデル化

(1) $y$ 方向流れ (嵌合部の隙間流れ)のモデル化

通気層のもつ開口または仮想室間の各隙間における圧 力損失をモデル化する。まず, 嵌合部の隙間の特性値の
うち不明なものは, 流れ指数 $n$, 等価な隙間幅 $d_{e}$, 流量 係数 $k_{y}$ である。

ここで, 隙間の前後に差圧 $\Delta P$ が生じたとき, 流れ指数 $n$ と流量 $Q$ の間には, 式(3)のような関係がある。

$$
Q=\alpha A\left(\frac{2 \Delta P}{\rho}\right)^{n}
$$

ここに, $Q$ : 隙間を通過する空気の流量 $\left[\mathrm{m}^{3} / \mathrm{h}\right], \alpha A$ : 等 価な隙間面積 $\left[\mathrm{m}^{2}\right]$ である。この関係を用いて嵌合部の隙 間の流れ指数 $n$ を算定するため, サイディングの前後に 差圧を与え, 流量計を用いて嵌合部を流れる空気の通気 量を測定する実験を行った。流量測定実験の結果を図 9 に示すが， $n_{y}=0.65$ のとき式(3)で実験結果を概ね近似で きるため, 嵌合部の隙間の流れ指数 $n_{y}$ は 0.65 と寸る。

次に, 単室試験体の実験を再現した $y$ 方向流れのみを 生じる 1 室モデルとして, 嵌合部隙間の流れに式(1)を適 用し, 実験の外圧時刻歷から裏面空間の圧力を計算した。 $d_{e}, k_{y}$ を変化させながらシミュレーションを行い, シミ ユレーションによる裏面空間の圧力が実験結果と一致す るような值の組み合わせとして $, d_{e}=2[\mathrm{~mm}], k_{y}=0.035$ を嵌合部の隙間流れの幅および流量係数に決定した。

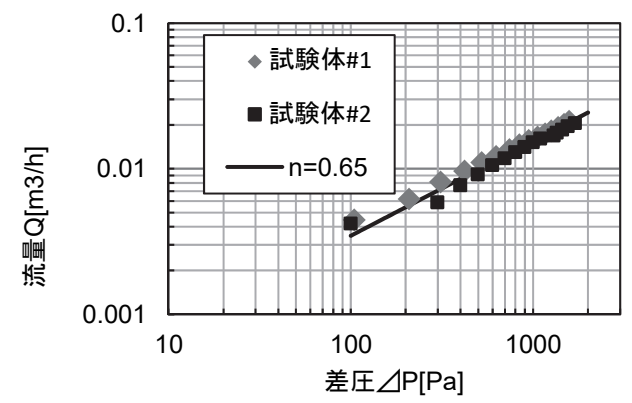

図 9 嵌合部の通気量測定結果

Fig.9 Air flow rate vs. differential pressure

(2) $z$ 方向流れ (通気層内の鉛直方向流れ) のモデル化

(1) と同様, アセンブリ試験体の通気層の体積と開口面 積を考慮した 4 室モデルを用いてシミュレーションを行 った。4 室モデルの概念図を図 10 に示す。 $L_{V}$ は仮想室高 さであり, 層内圧測定点間隔 $455 \mathrm{~mm}$ と寸る。 $L_{H}$ は縦胴 縁間の内法長さであり, 横張りでは $410 \mathrm{~mm}$, 縦張りでは $1755 \mathrm{~mm}$ となる。実際には 1 つの室に複数ある嵌合部の 隙間は，その総長さ分の開口を 1 か所にまとめる。各仮 想室には $y, z$ 方向の流れが生じるものとし,$y$ 方向の流 れには 4.2 (1) で求めた隙間の特性值を用い, $z$ 方向流 れの流量係数を変化させて実験を再現できる適当な值を 
決定する。 $z$ 方向流れが生じる箇所である上端開口，胴 縁間，下端開口では，それぞれ流れ性状が異なっている

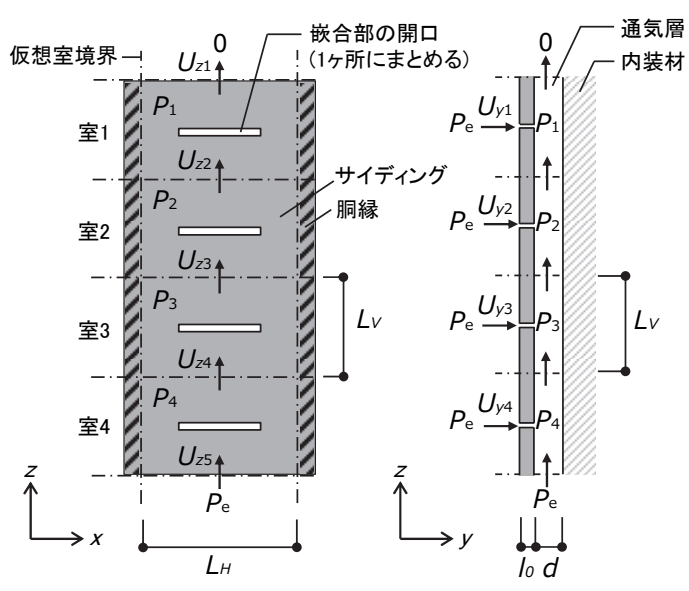

(a)立面図

(b)断面図

困 104 室モデルの概念困

Fig.10 Schematic illustration of a 4-room analysis model

と予想されるため, 各箇所の流量係数を $k_{z 1}, k_{z 2}, k_{z 3}$ とし, 適当な組み合わせを検討する。また，上下端開口部と胴 縁間の隙間 (または切欠き部) は通気層に対して卓越開口 とみなせるため, 流れ指数は $n=0.5$ とする。

図 11 に実験とシミュレーションによる内圧係数時刻 歴の例を示す。流量係数の值を変化させながらシミュレ ーションを行い，適当な值を与えることにより実験で得 られた層内圧の波形を概ね再現することができた。これ により決定した流量係数の值を表 2 に示す。

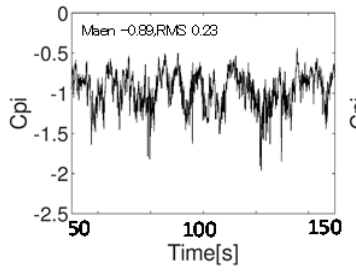

(a) 实験陋 (Line1)

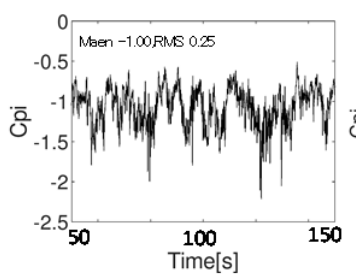

(c) 実験仵 (Line4)

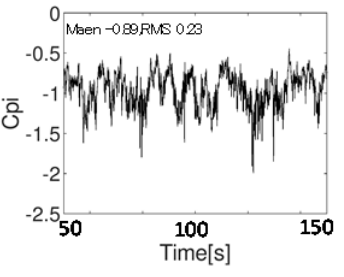

(b) シミュレーション (Line1)

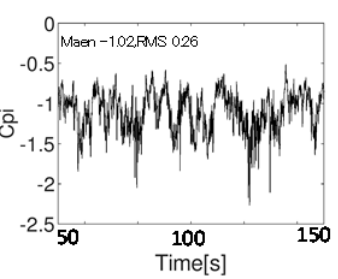

(d) シミュレーション (Line4)
図 11 内圧係数時刻歴（解析ケース：V-AH）

Fig.11 Time history of internal pressure coefficient
表 2 通気層の隙間および開口の流量係数

Table.2 Discharge coefficients of leakages

\begin{tabular}{|c|c|c|c|c|c|c|}
\hline \multirow{2}{*}{ ケース } & \multirow{2}{*}{ 通気層の仕様 } & $x$ 方向 & $y$ 方向 & \multicolumn{3}{|c|}{$z$ 方向 } \\
\hline & & $k_{x}$ & $k_{y}$ & $k_{z} 1$ & $k_{z^{2}}$ & $k_{z^{3}}$ \\
\hline V-C30 & 縦張り/C=30mm & \multirow{3}{*}{1.0} & \multirow{4}{*}{0.035} & 0.25 & 0.9 & 0.4 \\
\hline V-C60 & 縦張り $/ \mathrm{C}=60 \mathrm{~mm}$ & & & 0.25 & 0.9 & 0.4 \\
\hline V-AH & 縦張り/切欠き胴縁 & & & 0.18 & 0.65 & 0.7 \\
\hline $\mathrm{H}$ & 横張り & - & & 0.36 & 0.9 & 0.3 \\
\hline
\end{tabular}

5. 壁面モデルを用いた層内圧シミュレーション

5. 1 解析ケース

次に，風洞実験で対象とした建物の壁面全体に縦張り または横張りの胴縁およびサイディングを割り付け， 4 室モデルと同様の方法で仮想室分割を行った壁面モデル を作成する。各仮想室に近傍の測定点の外圧值を入力值 として与え，風洞実験で測定した全風向について層内圧 のシミュレーションを行う。なお, 通気層下端の開口に はその位置の外圧を作用させる。

解析ケースは表 1 に示寸通気層の仕様と図 12 に示寸上 端圧力状態を組み合わせた 16 ケースであり，「屋外開放」 の場合には，壁面上端部の外圧を上端に作用させる。ま た，小屋裏内圧は換気口に作用する圧力によって決まる が，小屋裏空間の体積は換気口からの空気の流入出量に 比べてかなり大きいため，時間的変動はわずかであり， 通気口付近の圧力と釣り合っているとみなせる。よって, 「小屋裏開放」の場合には小屋裏内圧の変動を無視し, 軒下換気，妻面換気，軒下妻面併用換気の 3 パターンの 換気方式について壁面の換気口位置(軒下換気の場合は 桁行面の軒下, 妻面換気の場合は屋根上端部付近) に近い 測定点の外圧を時間平均した值を風向ごとに求める。そ れを時間変動のない一定值として通気層上端の圧力値と して与えて計算を行う。

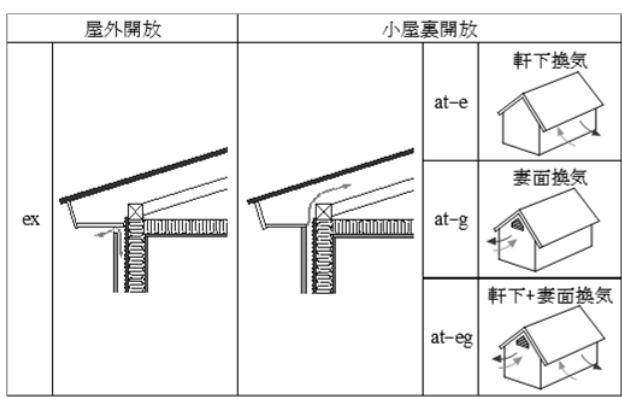

困 12 通気層の上端圧力状態のパラメータ

Fig. 12 Conditions of top opening of ventilated layer 
5. 2 シミュレーション結果

外装材の設計においては評価時間内での風力の最大 (正)および最小(負) ピーク值が重要となるため, 各部材 が負担するピーク風力の性状について検討する。ここで は, 外圧と層内圧の差をサイディングに作用する風力と 定義する。内装材の風力は層内圧と室内圧の差と定義す るが, 本研究では室内圧測定を行っていないので, 外圧 と層内圧の関係を単純に絶対值の大きさで比較できるよ うにするため室内圧を 0 と仮定し, 内装材の風力は層内 圧に等しいものとする。なお, サイディングと内装材に 作用する風力の関係を明らかにすることが目的であるた め, ピーク值は移動平均操作を行っていない 10 組の時刻 歴データから得られた值のアンサンブル平均で評価する。

まず, サイディングにとってクリティカルな荷重とな る負のピーク風力に着目する。図 13 に桁行面に作用する 負のピーク外圧係数 $C_{p e, \min }$ およびピーク風力係数 $C_{f, \mathrm{~min}}$ の 風向による変化を示寸。全風向中最大となるピーク值の 発生風向は, 外圧では $0^{\circ}$ であるのに対し, 風力では $20^{\circ}$ である。 $0^{\circ}$ と $20^{\circ}$ の場合の負のピーク外圧係数の分布を 図 14 に, 平均外圧係数分布を図 15 に示す。 2 つの風向 での最大のピーク外圧の発生位置はほぼ一致するが， $0^{\circ}$ のときの方が大きな負圧が広範囲に分布している。これ は角部における流れの剥離の影響であると考えられる。 一方, 図 16 のシミュレーションによる平均層内圧係数の 分布 $(\mathrm{V}-\mathrm{C} 30-\mathrm{ex}$ の場合)を見ると, 層内圧は外圧分布を 空間平均したような值となっており， $0^{\circ}$ の方が $20^{\circ}$ の きよりも絶対值が大きい。層内圧は外圧を相殺するよう に作用寸るので, $0^{\circ}$ の方が風力の低減効果が大きくなる。 以上より, ピーク外圧とサイディングのピーク風力は必 ずしも同じ風向で発生しないため, 等圧効果を考慮した ピーク風力の外圧に対する低減係数を決定する場合には, 全風向中のピーク外圧とピーク風力の差を求める必要が あると言える。

次に, 正のピーク風力に着目する。内装材は室内側か ら柱・梁等に留付けられるため, 正の層内圧がクリティ カルな荷重となる。図 17 には層内圧係数, 外圧係数およ び風力係数の正のピーク值と風向の関係を示す。屋外開 放の場合(図 17(a))を見ると, 外圧に比べてサイディン グに作用する風力が低減されている一方で, 外圧の 60〜 100\%の風力が内装材に作用している。また, 通気層仕様 によっても有意な差がみられ，通気層内の開口率が大き いほじ内装材に大きなピーク風力が作用している。横張 り仕様では層内圧が外圧を超えているが，これは通気層 内の空気の共鳴により層内圧が増幅された $\times C_{\rho e} \circ \bullet C_{f}: \mathrm{V}-\mathrm{C} 30 \diamond \diamond C_{f}: \mathrm{V}-\mathrm{C} 60 \square \square C_{f}: \mathrm{V}-\mathrm{AH} \quad \Delta \wedge C_{f}: \mathrm{H}$

白抜き記号 : 内装材の風力, 黒塗り記号 : サイディングの風力

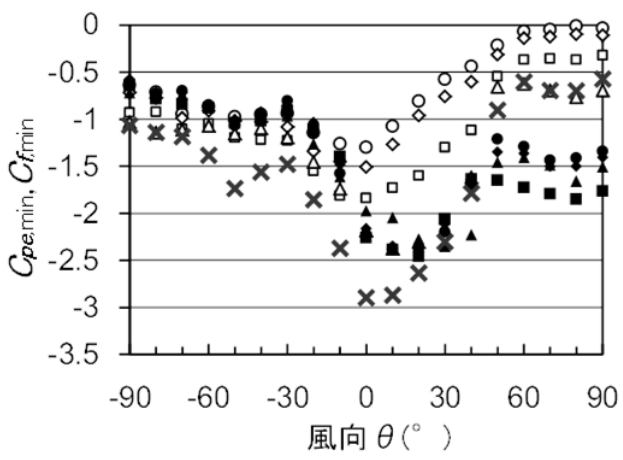

（a）屋外解放（ex）の場合

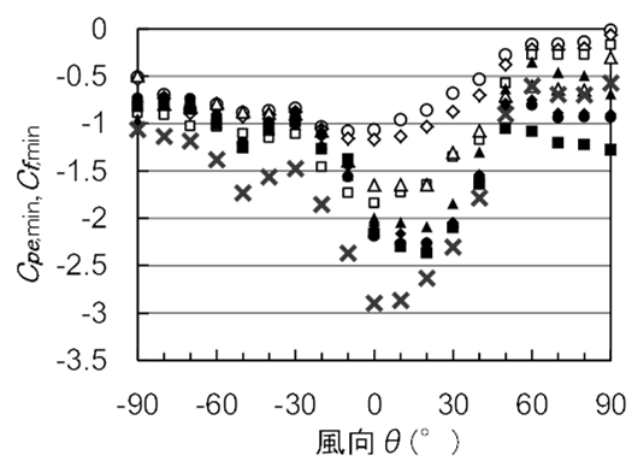

（b）小屋裏解放 · 軒下換気 (at-e) の場合

図 13 負のピーク外圧係数- 風力係数の風向変化(桁行面 の場合)

Fig.13 Negative peak pressure and wind force coefficients plotted against wind direction (side wall)

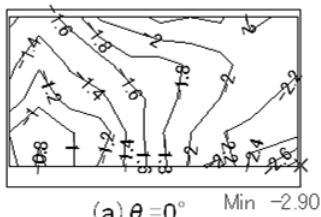

(a) $\theta=0$ Min -2.90

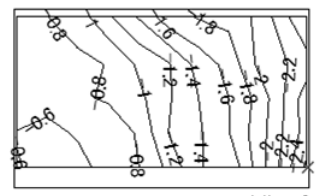

(b) $\theta=20^{\circ} \quad \operatorname{Min}-2.63$
図 14 負のピーク外圧係数分布 (桁行面)

Fig.14 Negative peak external pressure coefficients (side wall)

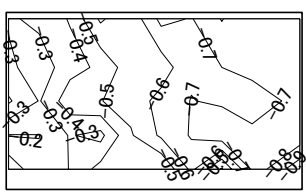

(a) $\theta=0^{\circ}$

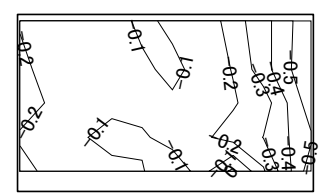

(b) $\theta=20^{\circ}$
図 15 平均外圧係数分布 (桁行面)

Fig. 15 Averaged external pressure coefficient (side wall) 


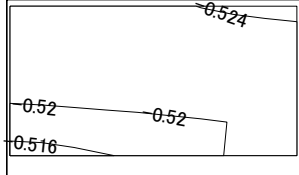

(a) $\theta=0^{\circ}$

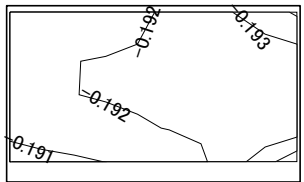

(b) $\theta=20^{\circ}$
図 16 シミュレーションによる平均層内圧係数分布(解 析ケース:V-C30-ex/桁行面)

Fig.16 Averaged internal pressure of ventilated layers obtained on side wall by simulation (case: $\mathrm{V}-\mathrm{C} 30-\mathrm{ex}$ )

$\times C_{\rho e} \circ \bullet C_{f}: \mathrm{V}-\mathrm{C} 30 \diamond \diamond C_{f}: \mathrm{V}-\mathrm{C} 60 \square C_{f}: \mathrm{V}-\mathrm{AH} \quad \triangle \Delta C_{f}: \mathrm{H}$

白抜き記号 : 内装材の風力, 黒塗り記号 : サイディングの風力

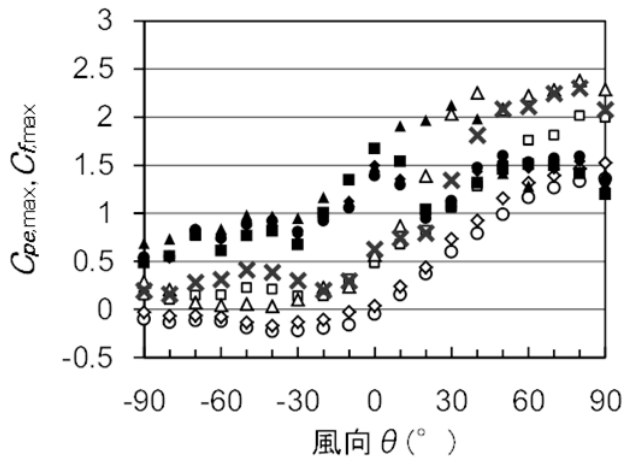

(a) 屋外解放 (ex) の場合

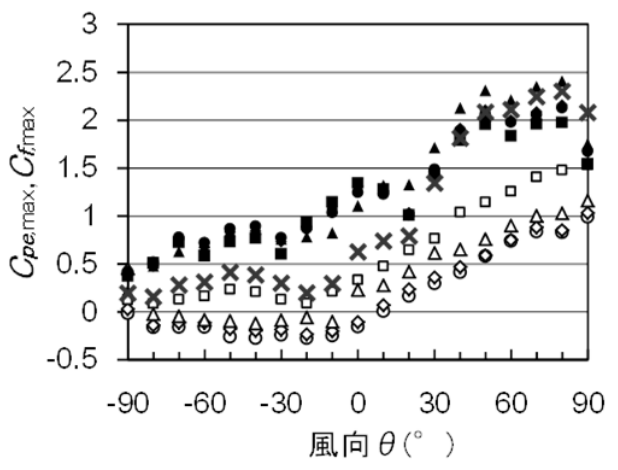

（b）小屋裏解放・軒下換気 (at-e)の場合

図 17 正のピーク内外圧係数-風力係数の風向変化 $($ 桁行 面の場合）

Fig.17 Positive peak pressure coefficients plotted against wind direction (side wall)

影響で外圧を超える大きなピークが発生したためである と考えられる。図 18 には正のピーク外圧が発生した風向 $\theta=80^{\circ}$ のときの桁行面の測定点 $\mathrm{p} 1 \sim \mathrm{p} 3$ (図 3 を参照)にお ける外圧と内圧のパワースペクトル密度を示す。特に横 張りの場合(図 $18(\mathrm{c})$ ) には, 外圧に見られない大きなピ 一クが見られ，通気層内空気の共鳴の影響が大きくなっ たと推測される。なお，この現象は実物大動風圧実験で
正圧を載荷した場合にも発生することを確認している。 また，小屋裏開放の場合には，換気方式に依らずほぼ同 じ傾向を示したため, 図 17 (b)には軒下換気の場合を示 すが，サイディングにはピーク外圧と同程度の荷重が風 力として作用する。一方，内装材のピークは外圧の 35〜 50\%程度であり，屋外開放の場合よりも内装材の負担が かなり低減されることが分かった。

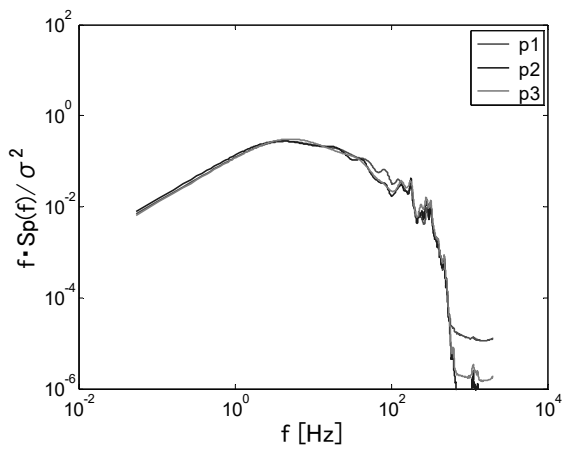

（a）外圧(風洞実験)

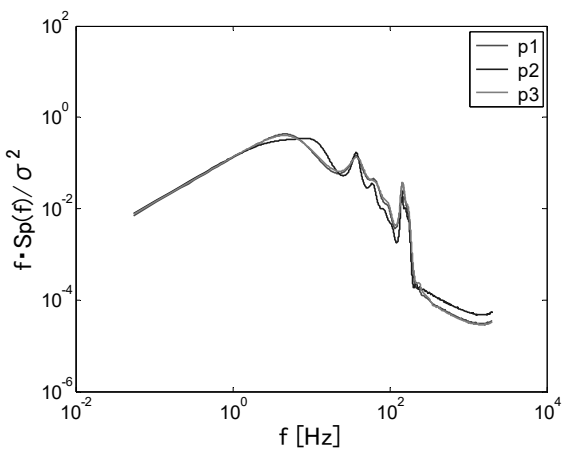

（b）層内圧(シミュレーション，解析ケース：V-C30-ex)

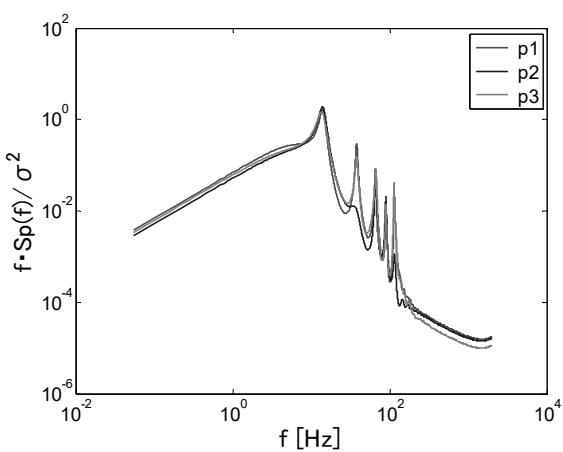

(c) 層内圧 (シミュレーション, 解析ケース : H-ex)

図 18 変動風圧のパワースペクトル密度(桁行面, 風向 $\left.\theta=80^{\circ}\right)$

Fig.18 Power spectra of external and internal pressure fluctuation (side wall, $\theta=80^{\circ}$ ) 
6．等圧効果を考慮した風荷重評価方法に関する提案

5.2ではシミュレーション結果より，ピーク外圧と サイディングおよび内装材のそれぞれに作用するピーク 風力の関係から，風力低減に影響の大きい因子について 考察した。通気層の仕様によっては, 荷重を負担する部 材や負担する風力の大きさが外圧に対して低減されたり， 従来風荷重を想定していない部材にも大きな風力が作用 したりする場合もある。そのため, 通気層の仕様に応じ て風力を負担寸る部材が異なることを考慮して風荷重評 価を行い，適切に設計を行う必要がある。

以上のような検討結果を踏まえ, 表 3 に示寸通気工法 による等圧効果を考慮した外壁システムの風荷重評価方 法と而風設計の考え方を提案する。負のピーク風力は, サイディングが負担しているが，等圧効果によって荷重 の大きさは外圧よりも低減される。一方, 正のピーク風 力については, 通気層上端の開放状態によって大きなピ 一ク風圧を負担寸る部材が異なるため, 屋外解放と小屋 裏解放の場合に分けている。屋外開放とする場合には, 内装材の負担するピーク風力が大きく, さらに通気層内 の開口率が大きくなるほど，すなわち胴縁間隔が広くな るほど増大寸るため, 通気層の仕様に応じて内装材に求 められる耐力の大きさが変わることに配慮した設計が必 要である。

\section{7.おわりに}

本研究では, 数值シミュレーションにより壁面に作用

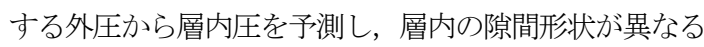
いくつかの場合について各部材の負担するピーク風力に ついて検討した。一般に, 通気層の部材構成は建物の建 設地・規模によって要求される防而火性能や断熱仕様の 選定によって決定されているが，外壁の強風被害を避け るためには, 各部材が負担する風力を適切に評価し, 通 気層仕様と使用する部材を決定することで合理的な而風 設計を行う必要がある。今後，本手法を応用し，意図的 に通気層の開口率を増やして風力低減効果を高める方法 で外壁の耐風性能を向上させる検討を行うことなども期 待される。

\section{謝辞}

本研究は, 平成 $28 \sim 29$ 年度科学研究費補助金(挑戦的 萌芽研究「等圧効果による風力低減と荷重再配分を利用 した高而風圧外壁システムの開発」(研究代表者・植松康) によるものである。

本研究を進めるにあたっては, アイジー工業(株)から 試験体用のサイディングの提供や工法に関する情報提供 をいただいた。ここに記して謝意を示す。

表 3 通気工法による外壁システムの風荷重評価方法と而風設計の考え方

Table 3 A method of evaluation of wind loads on ventilated exterior wall systems

\begin{tabular}{|c|c|c|}
\hline & 屋外開放とする場合 & 小屋裏開放とする場合 \\
\hline $\begin{array}{c}\text { 負のピーク } \\
\text { 風力 }\end{array}$ & \multicolumn{2}{|c|}{$\begin{array}{l}\text { 【サイディング】 } \\
\text { •サイディングが負担するピーク風力は外圧ピークより低減している。 } \\
\text { •ただし, 外圧とサイディング風力のピークは必ずしも同じ風向で発生しないため, 外圧ピークの発生風 } \\
\text { 向以外の風力についても検討を行ってピークの低減係数を算出する必要がある。 } \\
\text { 【内装材】 } \\
\text { •内装材には大きな風力は作用しない。 }\end{array}$} \\
\hline $\begin{array}{c}\text { 正のピーク } \\
\text { 風力 }\end{array}$ & $\begin{array}{l}\text { 【サイディング】 } \\
\text { •サイディングのピーク風力は, ピーク外圧の風向 } \\
\text { 発生で求めた低減係数をいて用い低減できる。 } \\
\text { 【内装材】 } \\
\text { •内装材のピーク風力は通気層内の開口率が大きく } \\
\text { なるほど増加するため, 通気層の仕様と使用する内 } \\
\text { 装材の組み合わせへの配慮が必要である。 }\end{array}$ & $\begin{array}{l}\text { 【サイディング】 } \\
\text { •サイディングはピーク外圧と同等の風力を負担す } \\
\text { る。 } \\
\text { 【内装材】 } \\
\text { •内装材に作用する風力はピーク外圧より軽減され } \\
\text { るものの, 通気層内の開口率によっては荷重が大き } \\
\text { くなる場合もある。 }\end{array}$ \\
\hline
\end{tabular}




\section{参考文献}

1）日本建築学会, 建築物荷重指針・同解説 (2015), 2015.

2）ガヴァンスキ 江梨, 高橋 麻衣, 植松 康, モリソン マ リー, 実変動風荷重載荷装置の性能評価, 日本建築学 会技術報告集，21，49，pp.1075-1080，2015.

3）アイジー工業株式会社, アイジーサイディング施工説 明書 新築用 2017 年 9 月版, 2017.

4) Jeong Hee Oh, Gregory A. Kopp, Diana R. Inculet, "The UWO contribution to the NIST aerodynamic database for wind loads on low buildings: Part3.Internal pressures", Journal of Wind Engineering and Industrial Aerodynamics Vol.95, pp.755-779, 2007. 